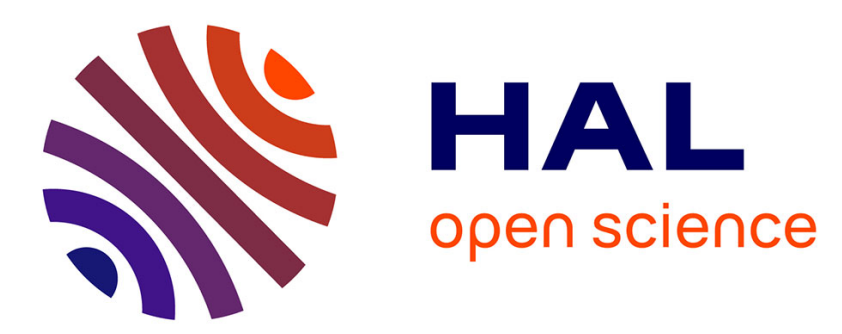

\title{
Sodium Dihydrogen Phosphate Starting From Sodium Chloride and Orthophosphoric Acid Via Cation Resin Exchange
}

Doan Pham Minh, Ange Nzihou, Patrick Sharrock

\section{- To cite this version:}

Doan Pham Minh, Ange Nzihou, Patrick Sharrock. Sodium Dihydrogen Phosphate Starting From Sodium Chloride and Orthophosphoric Acid Via Cation Resin Exchange. Phosphorus, Sulfur, and Silicon and the Related Elements, 2015, 190 (11), p. 1743-1748. 10.1080/10426507.2015.1024314. hal-01609203

\section{HAL Id: hal-01609203 https://hal.science/hal-01609203}

Submitted on 20 Oct 2018

HAL is a multi-disciplinary open access archive for the deposit and dissemination of scientific research documents, whether they are published or not. The documents may come from teaching and research institutions in France or abroad, or from public or private research centers.
L'archive ouverte pluridisciplinaire HAL, est destinée au dépôt et à la diffusion de documents scientifiques de niveau recherche, publiés ou non, émanant des établissements d'enseignement et de recherche français ou étrangers, des laboratoires publics ou privés. 


\title{
SODIUM DIHYDROGEN PHOSPHATE STARTING FROM SODIUM CHLORIDE AND ORTHOPHOSPHORIC ACID VIA CATION RESIN EXCHANGE
}

\author{
Doan Pham Minh, Ange Nzihou, and Patrick Sharrock Universite' de \\ Toulouse, Mines Albi, CNRS UMR 5302, Centre RAPSODEE, Campus Jarlard,F-81013 \\ Albi Cedex 09, France
}
GRAPHICAL ABSTRACT
$\mathrm{R}-\mathrm{SO}_{3}-\mathrm{H}+\mathrm{NaCl} \rightarrow \mathrm{R}-\mathrm{SO}_{3}-\mathrm{Na}+\mathrm{HCl}$
(step 1)
$\mathrm{R}-\mathrm{SO}_{3}-\mathrm{Na}+\mathrm{H}_{3} \mathrm{PO}_{4} \rightarrow \mathrm{R}-\mathrm{SO}_{3}-\mathrm{H}+\mathrm{NaH}_{2} \mathrm{PO}_{4} \quad$ (step 2)

$\mathrm{NaCl}+\mathrm{H}_{3} \mathrm{PO}_{4} \rightarrow \mathrm{NaH}_{2} \mathrm{PO}_{4}+\mathrm{HCl}$

\begin{abstract}
Sodium phosphates are generally synthesized by neutralization of orthophosphoric acid with sodium hydroxide. In this paper, we communicate a new synthesis process, wherein sodium dihydrogen phosphate can be obtained from sodium chloride and orthophosphoric acid, using cation resin exchange at room operational conditions. This opens a new concept for the design of environmentally friendly processes in this inorganic synthesis field.
\end{abstract}

Keywords Synthesis design; ion exchange; cations; sodium dihydrogen phosphate

\section{INTRODUCTION}

Sodium phosphates include a family of several inorganic compounds. At least 15 solid sodium phosphates exist in the temperature range from 25 to $100^{\circ} \mathrm{C}$ (Table 1). ${ }^{1,2}$ Many of them are commonly used as food additives, in $\mathrm{pH}$ control, and in detergent composition., ${ }^{2,3}$ They can be also used in catalysis, ${ }^{4}$ and as starting materials for the synthesis of other phosphates, such as sodium trimetaphosphate, ${ }^{5-8}$ phosphate-based glasses and alloys, ${ }^{9-13}$ apatitic calcium phosphates. ${ }^{14-17}$

Sodium phosphates can be classically obtained from the neutralization of orthophosphoric acid with sodium hydroxide (and sometimes with sodium carbonate). ${ }^{3}$ However, sodium hydroxide is industrially produced from the electrolysis of sodium chloride solution. ${ }^{18}$ Considering sodium chloride and orthophosphoric acid as starting materials, sodium phosphates are formed by multi-step synthesis process (Equations (1-2)) which release chlorine.

Address correspondence to Doan Pham Minh, Université de Toulouse, Mines Albi, CNRS UMR 5302, Centre RAPSODEE, Campus JarlardF-81013 Albi Cedex 09, France. E-mail: doan.phamminh@mines-albi.fr 
Table 1 List of solid crystalline sodium phosphates existing at the temperature range of 25 to $100^{\circ} \mathrm{C}$

\begin{tabular}{lll}
\hline $\mathrm{NaH}_{2} \mathrm{PO}_{4}$ & $\mathrm{Na}_{2} \mathrm{HPO}_{4}$ & $\mathrm{Na}_{3} \mathrm{HPO}_{4}$ \\
$\mathrm{NaH}_{2} \mathrm{PO}_{4} \cdot \mathrm{H}_{2} \mathrm{O}$ & $\mathrm{Na}_{2} \mathrm{HPO}_{4} \cdot 2 \mathrm{H}_{2} \mathrm{O}$ & $\mathrm{Na}_{3} \mathrm{HPO}_{4} \cdot 0.5 \mathrm{H}_{2} \mathrm{O}$ \\
$\mathrm{NaH}_{2} \mathrm{PO}_{4} \cdot 2 \mathrm{H}_{2} \mathrm{O}$ & $\mathrm{Na}_{2} \mathrm{HPO}_{4} \cdot 7 \mathrm{H}_{2} \mathrm{O}$ & $\mathrm{Na}_{3} \mathrm{HPO}_{4} \cdot 6 \mathrm{H}_{2} \mathrm{O}$ \\
$\mathrm{NaH}_{2} \mathrm{PO}_{4} \cdot \mathrm{Na}_{2} \mathrm{HPO}_{4}$ & $\mathrm{Na}_{2} \mathrm{HPO}_{4} \cdot 8 \mathrm{H}_{2} \mathrm{O}$ & $\mathrm{Na}_{3} \mathrm{HPO}_{4} \cdot 8 \mathrm{H}_{2} \mathrm{O}$ \\
$\mathrm{NaH}_{2} \mathrm{PO}_{4} \cdot \mathrm{H}_{3} \mathrm{PO}_{4}$ & $\mathrm{Na}_{2} \mathrm{HPO}_{4} \cdot 12 \mathrm{H}_{2} \mathrm{O}$ & $\mathrm{Na}_{3} \mathrm{HPO}_{4} \cdot 12 \mathrm{H}_{2} \mathrm{O}$ \\
\hline
\end{tabular}

$$
\begin{array}{r}
2 \mathrm{NaCl}+2 \mathrm{H}_{2} \mathrm{O} \rightarrow 2 \mathrm{NaOH}+\mathrm{Cl}_{2}+\mathrm{H}_{2} \\
\mathrm{NaOH}+\mathrm{H}_{3} \mathrm{PO}_{4} \rightarrow \mathrm{NaH}_{2} \mathrm{PO}_{4}+\mathrm{H}_{2} \mathrm{O}
\end{array}
$$

This study aimed to design a new process for getting sodium phosphates directly from sodium chloride and orthophosphoric acid as starting materials, in order to simplify and economize cost and energy of the existing process. This calls for the cationic exchange property of resin-based materials. A given cationic exchange resin contains generally a stable polymer matrix (R-) and functional groups such as sulfonic acid $\left(-\mathrm{SO}_{3}-\mathrm{H}\right)$. The proton $\left(\mathrm{H}^{+}\right)$of these functional groups can be exchanged with other cations such as $\mathrm{Na}^{+}$ and this process is generally reversible. Our synthesis process can be summarized by Equations (3-4). The first step (Equation (3)) is for fixing the sodium cations on the resin matrix and for releasing $\mathrm{HCl}$ as the co-product of the process. The second step (Equation (4)) is for regenerating the acidic resin matrix and for forming $\mathrm{NaH}_{2} \mathrm{PO}_{4}$ as the desired product.

$$
\begin{array}{r}
\mathrm{R}-\mathrm{SO}_{3}-\mathrm{H}+\mathrm{NaCl} \rightarrow \mathrm{R}-\mathrm{SO}_{3}-\mathrm{Na}+\mathrm{HCl} \\
\mathrm{R}-\mathrm{SO}_{3}-\mathrm{Na}+\mathrm{H}_{3} \mathrm{PO}_{4} \rightarrow \mathrm{R}-\mathrm{SO}_{3}-\mathrm{H}+\mathrm{NaH}_{2} \mathrm{PO}_{4}
\end{array}
$$

\section{RESULTS AND DISCUSSION}

Three liquid flow rates of 2,10 , and $20 \mathrm{~mL} \mathrm{~min}^{-1}$ of both $\mathrm{NaCl}$ and $\mathrm{H}_{3} \mathrm{PO}_{4}$ solutions were investigated. Table 2 summarizes the results of sodium exchange yield, corresponding to Step 1. For sodium exchange, the quantity of sodium exchanged with the column varied between 17.4 and $20.5 \mathrm{mmol}$ corresponding to the exchange yields of 51-60\% (the exchange capacity of the column was $29.8 \mathrm{mEq}$.). This might be due to the quantity of sodium introduced into the column $(34 \mathrm{mmol})$, which was only slightly higher than the capacity of the column. Contrary to what we expected, the decrease of the liquid flow rate (in the range 2-20 mL min ${ }^{-1}$ ) led to a slight decrease of the sodium exchange yield. The analysis of the chloride showed that the resin matrix practically had no interaction with

Table 2 Sodium exchange during the step 1 of the synthesis process at room temperature and pressure

\begin{tabular}{lcccc}
\hline $\begin{array}{l}\text { Liquid flow rate } \\
\left(\mathrm{mL} \mathrm{min}{ }^{-1}\right)\end{array}$ & $\begin{array}{c}\text { Na introduced } \\
(\mathrm{mmol})\end{array}$ & $\begin{array}{c}\text { Na captured by the } \\
\text { column }(\mathrm{mmol})\end{array}$ & $\begin{array}{c}\mathrm{Cl}^{-} \text {introduced } \\
(\mathrm{mmol})\end{array}$ & $\begin{array}{c}\mathrm{Cl}^{-} \text {outlet } \\
(\mathrm{mmol})\end{array}$ \\
\hline 2 & 34 & 17.4 & 34 & 34 \\
10 & 34 & 18.5 & 34 & 33.9 \\
20 & 34 & 20.5 & 34 & 34 \\
\hline
\end{tabular}


Table 3 Sodium release during the step 2 of the synthesis process at room temperature and pressure

\begin{tabular}{lcccc}
\hline $\begin{array}{l}\text { Liquid flow rate } \\
\left(\mathrm{mL} \mathrm{min}{ }^{-1}\right)\end{array}$ & $\begin{array}{c}\text { Na available in the } \\
\text { column (mmol) }\end{array}$ & $\begin{array}{c}\text { Na released by the } \\
\text { column (mmol) }\end{array}$ & $\begin{array}{c}\mathrm{PO}_{4}{ }^{3-} \text { introduced } \\
(\mathrm{mmol})\end{array}$ & $\begin{array}{c}\mathrm{PO}_{4}{ }^{3-} \text { outlet } \\
(\mathrm{mmol})\end{array}$ \\
\hline 2 & 17.4 & 4.6 & 34 & 33.8 \\
10 & 18.5 & 5.2 & 34 & 34 \\
20 & 20.5 & 4.0 & 34 & 34 \\
\hline
\end{tabular}

chloride anions. The aqueous solution recovered from the outlet of the reactor during this step 1 contained 17.4-20.5 mmol of $\mathrm{HCl}$ and 16.6-13.5 mmol of $\mathrm{NaCl}$.

Table 3 shows the results obtained for Step 2 at three different liquid flow rates. When orthophosphoric (34 mmol) passed through the column, all phosphate anions left

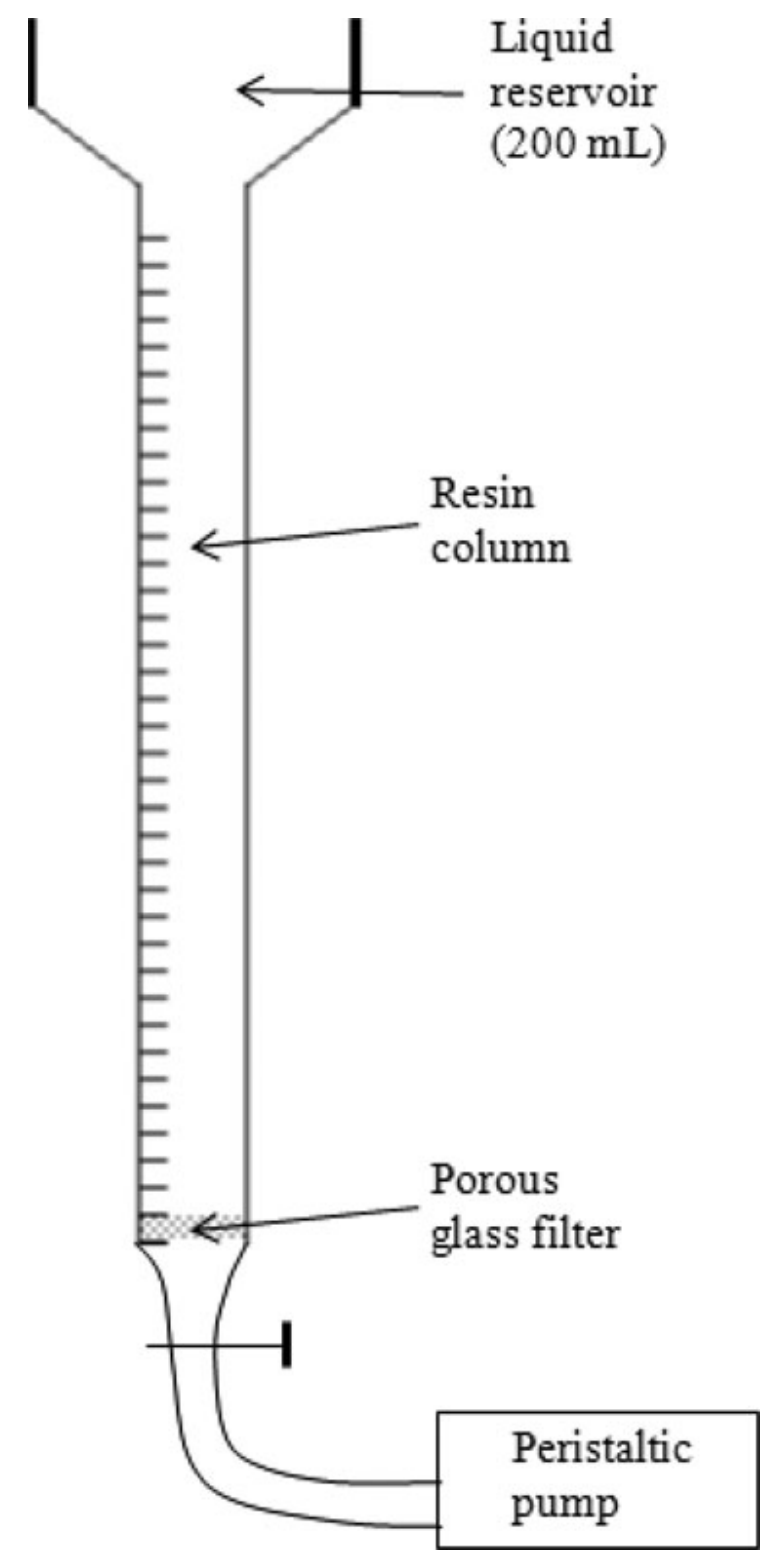

Figure 1 Illustration of the resin column used in this work. 
the column, indicating that the resin had no affinity for this anion. For sodium cations previously fixed on the column at Step 1, they were only partially released from the column. As observed for Step 1, the liquid flow rate did not have a notable influence on the release of sodium. The aqueous solution recovered from Step 2 of this synthesis process contained 4.0-5.2 mmol of $\mathrm{NaH}_{2} \mathrm{PO}_{4}$ and 28.8-30.0 mmol of $\mathrm{H}_{3} \mathrm{PO}_{4}$. This corresponded to the final yield of both steps 1 and 2 of the process of $11-15 \%$. The difficulty of sodium release during the step 2 may be explained by the low dissociation constant of orthophosphoric acid $\left(K_{a l}\right.$ equal to $\left.7.25 \times 10^{-3}\right)$, compared to the strength of the sulfonate groups on the resin. At ambient temperature, the $\mathrm{pH}$ of the dilute aqueous solution of orthophosphoric acid of $100 \mathrm{mM}$ was measured and equal to 1.6. At this $\mathrm{pH}$, the species distribution of orthophosphoric acid was as following: $83.7 \%, 16.3 \%, 0 \%$, and $0 \%$ for $\mathrm{H}_{3} \mathrm{PO}_{4}, \mathrm{H}_{2} \mathrm{PO}_{4}{ }^{-}$, $\mathrm{HPO}_{4}{ }^{2-}$, and $\mathrm{PO}_{4}{ }^{3-} \cdot{ }^{17}$

These first results show that it is possible to obtain monobasic sodium phosphate via cationic exchange process. The advantages of this process are: its operational simplicity; its moderate reaction conditions (room temperature and pressure); and the separation of two main products of the process (obtaining $\mathrm{HCl}$ in the step 1, and $\mathrm{NaH}_{2} \mathrm{PO}_{4}$ in the step 2). However, the performance of the process needs to be improved. For this last, we think that the choice of resin plays an important role. The resin used in this work $\left(\mathrm{R}-\mathrm{SO}_{3}-\mathrm{H}\right)$ contains strong acid groups. Sodium cations fixed by sulfonate groups are difficult to remove with orthophosphoric acid, having low acidity. A resin containing weaker acid groups (R-COO$\mathrm{H}$ for example), which should easily participate in the cationic exchange with both $\mathrm{NaCl}$ and $\mathrm{H}_{3} \mathrm{PO}_{4}$ solutions seems to be necessary for improving the performance of the process. This will be tried in future work.

\section{CONCLUSIONS}

For the first time, the synthesis of sodium phosphate from $\mathrm{NaCl}$ and $\mathrm{H}_{3} \mathrm{PO}_{4}$ via cationic exchange process was reported. Using the resin containing sulfonic acid $\left(-\mathrm{SO}_{3}-\mathrm{H}\right)$ as functional groups, the final yield of the process reached $15 \%$. The use of other resins having weaker acid groups seems to be a key factor for improving the performance of the process.

\section{EXPERIMENTAL}

$\mathrm{NaCl}$ powder (Fisher Scientific, $>99 \%$ ), $\mathrm{HCl}$ (Fisher Scientific, $36 \mathrm{wt} . \%$ in water), and orthophosphoric acid ( $85 \mathrm{wt} . \%$ in water, Merck) were used for the preparation of aqueous solutions containing $100 \mathrm{mM}$ of $\mathrm{NaCl}, \mathrm{HCl}$, and $\mathrm{H}_{3} \mathrm{PO}_{4}$. Elemental analysis of liquid samples was performed by inductive coupled plasma atomic emission spectroscopy (ICPAES, HORIBA Jobin Yvon Ultima 2). Phosphate anion $\left(\mathrm{PO}_{4}{ }^{3-}\right)$ and chloride anion $\left(\mathrm{Cl}^{-}\right)$ of liquid samples was analyzed by ion chromatography (Dionex, conductivity detector, Dionex IonPac AS 19 column $(4 \times 250 \mathrm{~mm}))$.

In the first step, we tested a commercial resin, which was purchased from Aldrich (Amberlite IR120). This resin is composed of styrene-divinylbenzene as resin matrix (R-) and sulfonic acid $\left(-\mathrm{SO}_{3}-\mathrm{H}\right)$ as functional groups. The cationic exchange capacity of this resin was $1.356 \mathrm{mEq}$ per $\mathrm{mL}$ of resin, which was experimentally determined. Spherical resin particles of diameter of 297-1190 $\mu \mathrm{m}$ were used as received.

The cationic exchange process was carried out at ambient temperature and pressure, using a graduated glass column (internal diameter of $10 \mathrm{~mm}$, height of $250 \mathrm{~mm}$ ) (Fig. 1). 
A porous glass disk (porosity of 101-160 $\mu \mathrm{m}$ ) was set at the bottom of the column in order to keep the bed of resin particles in the column. The outlet of the column was connected with a peristaltic pump for the control of liquid flow rate. The procedure for a given test was the following:

- Step 0: The column was filled with resin particles for the apparent volume of $22 \mathrm{~mL}$. Then, it was completed with pure water in order to facilitate the contact of reactants with resin particles during exchange process. The cationic exchange capacity of the column was $29.8 \mathrm{mEq}$. The same resin sample was used for all the tests in this report.

- Step 1: The resin in the column was in the protonated form $\left(\mathrm{R}_{-} \mathrm{SO}_{3}-\mathrm{H}\right)$. For the first synthesis step (Equation (3)), $340 \mathrm{~mL}$ of $\mathrm{NaCl}(100 \mathrm{mM})$ passed through the column at the liquid flow rate of $2-20 \mathrm{~mL} \mathrm{~min}^{-1}$, followed by rinsing with $50 \mathrm{~mL}$ of water.

- Step 2: The resin was now saturated with sodium cations ( $\left.\mathrm{R}-\mathrm{SO}_{3}-\mathrm{Na}\right)$. For the second synthesis step (Equation (4)), $340 \mathrm{~mL}$ of $\mathrm{H}_{3} \mathrm{PO}_{4}(100 \mathrm{mM})$ passed through the column at the same liquid flow rate as for the first synthesis step $(2-20 \mathrm{~mL})$. The column was also rinsed with $50 \mathrm{~mL}$ of water.

- Step 3: To regenerate the column, $340 \mathrm{~mL}$ of $\mathrm{HCl}(100 \mathrm{mM})$ was pumped through the column at the flow rate of $2 \mathrm{~mL} \mathrm{~min}{ }^{-1}$. This quantity of $\mathrm{HCl}$ was largely sufficient for acidifying the quantity of resin present in the column. Then, the column was rinsed with $50 \mathrm{~mL}$ of water following the regeneration.

For all the steps 1 to 3, the total quantity of liquid phase from the outlet of the reactor (including rinsing water) was recovered. ICP-AES and ion chromatography were carried out for determining the content of sodium, chloride, and phosphate. This allowed calculating the mass balance of each component.

The final yield for the formation of $\mathrm{NaH}_{2} \mathrm{PO}_{4}$ of both steps 1 and 2 of the process is calculated according to the following equation:

$$
Y=\frac{N a_{\text {released }}}{N a_{i}} \times 100
$$

where $Y$ is the final yield of both steps 1 and 2 of the process for the formation of $\mathrm{NaH}_{2} \mathrm{PO}_{4}$; $N a_{\text {released }}$ is the value of "Na released by the column, mmol" in Table $3 ; N a_{i}$ is the initial quantity of sodium chloride introduced into the column in Step 1 which is equal to the initial quantity of orthophosphoric acid introduced into the column in Step 2 (or $34 \mathrm{mmol}$ ).

\section{ACKNOWLEDGMENTS}

The authors gratefully acknowledge colleagues at RAPSODEE Center for technical help.

\section{REFERENCES}

1. Wendrow, B.; Kobe, K. A. Chem. Rev. 1954, 54, 891-924.

2. Gilmour, R. Phosphoric Acid Purification, Uses, Technology, and Economics, CRC Press: Boca Raton-London-New York, 2013; pp. 203-213.

3. Corbridge, D. E. C. Studies in Inorganic Chemistry 10. Phosphorus: An Outline of its Chemistry, Biochemistry and Technology, 4th ed.; Elsevier: Amsterdam-Oxford-New York-Tokyo, 1990; pp. 172-210.

4. Karimi-Jaberi, Z.; Barekat, M. Chin. Chem. Let. 2010, 21, 1183-1186. 
5. Thilo, E. H.; Grunze, H. Z. Anorg. Allg. Chem. 1955, 281, 262-283.

6. Pham Minh, D.; Ramaroson, J.; Nzihou, A.; Sharrock, P.; Depelsenaire, G. Phosphorus Sulfur Silicon Relat. Elem. 2012, 187, 112-120.

7. Pham Minh, D.; Ramaroson, J.; Nzihou, A.; Sharrock, P. Phosphorus Sulfur Silicon Relat. Elem. 2012, 187, 1132-1140.

8. Pham Minh, D.; Ramaroson, J.; Nzihou, A.; Sharrock, P. Ind. Eng. Chem. Res. 2012, 51, 38513854.

9. Ravikumar, R. V. S. S. N.; Chandrasekhar, A. V.; Ramamoorthy, L.; Reddy, B. J.; Reddy, Y. P.; Yamauchi, J.; Rao, P. S. J. Alloy. Compd. 2004, 364, 176-179.

10. Abdelghany, A. M.; ElBatal, F. H.; El-Batal, H. A.; Ezz-El-Din, F. M. J. Mol. Struct. 2014, 1074, 503-510.

11. Shih, P. Y. Mater. Chem. Phys. 2004, 84, 151-156.

12. Guler, H.; Kurtulus, F. Mater. Chem. Phys. 2006, 99, 394-397.

13. Yang, Y.; Dai, G.; Tan, S.; Liu, Y.; Shi, Q.; Ouyang, Y. J. Rare Earth. 2011, 29, 308-312.

14. Bigi, A.; Boanini, E.; Borghi, M.; Cojazzi, G.; Panzavolta, S.; Roveri, N. J. Inorg. Biochem. 1999, 75, 145-151.

15. Arellano-Jimenez, M. J.; Garcia-Garcia, R.; Reyes-Gasga, J. J. Phys. Chem. Solids 2009, 70, 390-395.

16. Jokic, B.; Mitric, M.; Radmilovic, V.; Drmanic, S.; Petrovic, R.; Janackovic, D. Ceram. Int. 2011, 37, 167-173.

17. Pham Minh, D.; Lyczko, N.; Sebei, H.; Nzihou, A.; Sharrock, P. Mater. Sci. Eng. B 2012, 177, 1080-1089.

18. Tilley R. J. D. Understanding Solids: The Science of Materials, John Wiley and Sons: New Delhi, 2004, pp. 281. 